\title{
The Effect of Constructive Imaginative Mind Maps, Vee Maps, and Concept Maps on Students' Attitude and Ability to Write Short Stories at Senior High School (SMAN) 13 Palembang
}

\section{Ernalida ${ }^{1}$ and A. Ayo b²}

${ }^{1}$ Indonesian Language Education Study Program, Department of Education Language and Art, Faculty of Teacher Training and Education, Universitas Sriwijaya, Jalan Srijaya Negara, Palembang, South Sumatra 30128, Indonesia

${ }^{2}$ Faculty of Language and Communication, Sultan Idris Education University, Tanjong Malim, Perak Darul Ridzuan 35900, Malaysia

\section{Abstract}

Corresponding Author:

Ernalida

ernalidapurnama@yahoo.co.id

Received: 6 April 2018

Accepted: 3 May 2018

Published: 26 July 2018

Publishing services provided by Knowledge $\mathrm{E}$

(c) Ernalida and A. Ayob. This article is distributed under the terms of the Creative Commons Attribution License, which permits unrestricted use and redistribution provided that the original author and source are credited.

Selection and Peer-review under the responsibility of the ISLLE 2017 Conference Committee.
This study aimed to determine the effect of constructive imaginative mind maps, vee maps, and concept maps on students' attitude and ability to write short stories at SMA 13 Palembang. The research method used was an experimental design. The population of this study was all students of the XI grade at SMA Negeri 13 Palembang. The sample consisted of three classes, namely XI grade MIA 2 with 38 students, XI grade MIA 3 with 36 students, and 32 students from XI grade MIA 4. The instruments used to collect data were tests of short story writing skills and attitude questionnaires using the Likert scale. A one-way Anova test was used to analyze short story data and Mancova was used to analyze the students' attitudinal data. The results showed that the students' scores and attitudes with the use of constructive imaginative mind maps in learning to write short stories were higher than with the use of vee maps and concept maps. The implication of this research is that Indonesian teachers can use constructive imaginative mind maps to improve students' writing skills and attitude.

Keywords: concept map, constructive imaginative, mind mapping, students' attitude, vee map, writing short stories

\section{Introduction}

In Indonesia, Bahasa Indonesia, especially writing skills, is one of the academic areas that must be studied by high school (SMA) students. In reality, however, this is not particularly desirable for students. The results of learning to write short stories thus 
far are still very low. The research results of Susiawati [1] indicated that the learning of writing short stories is still at a low level and remains unpopular among students.

Writing short stories requires capability in several aspects, such as choosing the theme, the flow, the message to be conveyed, the characters, the attributes, and the style of the language using the literary barrel [2]. The use of language in writing short stories is the ability of an author to use or play with a variety of specific languages during the process of writing a literary work [3]. This is an obstacle for students in writing short stories. In addition, the use of conventional learning techniques also helps to increase students' difficulties in writing short stories.

Students' creativity in writing a short story is very important. Writing is a process of finding ideas, organizing ideas, and writing down ideas with a view to editing and revising essays [4]. In learning bahasa Indonesia, one form of creativity can be seen from the results of the essay.

In the 2013 curriculum, one of the basic competencies that must be achieved in learning bahasa Indonesia in XI grade is "producing a short story text that is coherent in accordance with the characteristics of the text that will be composed, either orally or in writing."This competency has to be achieved by the students, but in reality, it is poorly controlled by them. Therefore, teachers need to apply appropriate techniques in learning, especially in terms of producing or writing short stories.

One learning technique that has been proven to optimize learning outcomes is mind mapping. The concept of mind mapping was originally introduced by Tony Buzan in the 1970s. This technique is also known as "radiant thinking." Mind mapping is very effective when it is used to bring up hidden ideas and create an association between ideas. Mind mapping is also useful for organizing information owned. According to Hernowo [5], mind mapping makes students relate to the subconscious mind before writing; writing becomes more emotional, more colorful, more rhythmic. The writing, in turn, reflects the personal characteristics more accurately. In mind mapping, the brain's working system is naturally regulated. Automatic work is in accordance with the natural human way of thinking. Mind mapping makes the human brain well explored, and works according to its function.

Constructive Imaginative Mind Map (CIMM) is a teaching aid adapted from Buzan's mind mapping that involves the mind in writing short stories. This CIMM activates students' thinking patterns based on existing knowledge by engaging the imagination of a story. Students imagine the content of stories, figures, characterizing, plot, point of view, and the language used in writing short stories. 
Mind mapping is a learning material developed by Tony Buzan in the early 1970 . A very remarkable data storage and retrieval system exists within the human brain [6]. Mahamod [7] suggests that mind mapping can help learners to improve their intelligence and thinking skills.

In writing, it is very important to think of essays in the form of mind mapping. Moreover, writing for the purpose of literature such as short stories has stylistic characteristics, in other words the style of writing, including the structure and patterns at the phrase level and overall essay [8]. Therefore, the mind mapping can provide an image that matches the theme or issue of the essay [9].

There are 10 steps required to create a CIMM:

(a) Writing a short story theme in the middle of a piece of blank paper with one or two words.

(b) Writing a picture of the contents of the short story on the first branch of the character's activities such as birthday parties.

(c) Writing down the background of the story on the second arch.

(d) Writing down what conflicts occur in the short story in the third arch.

(e) Writing a rating of the short story, e.g. an assessment of the character in the fourth arch.

(f) Writing the ending of the short story on the fifth arch.

(g) Writing an event at the end of the short story to mark that the short story is over.

(h) Adding a curve in the second, third and so on according to the imagination.

(i) Coloring the CIMM images that have been formed as you wish.

(j) Writing short stories according to the theme, and CIMM images using correct sentences, vocabulary and spelling.

A vee map is often also called a "vee diagram." A vee map is a tool that can be used to help solve a problem or understand a procedure. A vee map has two sides: the conceptual side and the methodological side. The two sides interact with each other to build student knowledge in writing short stories. Vee map images can be as follows.

A concept map (CM) is a learning material used in class activities in the form of diagrams that connect ideas with each other in writing a short story. A concept map is a combination of a theme, content, opinions, ideas, and responses that is then shaped 


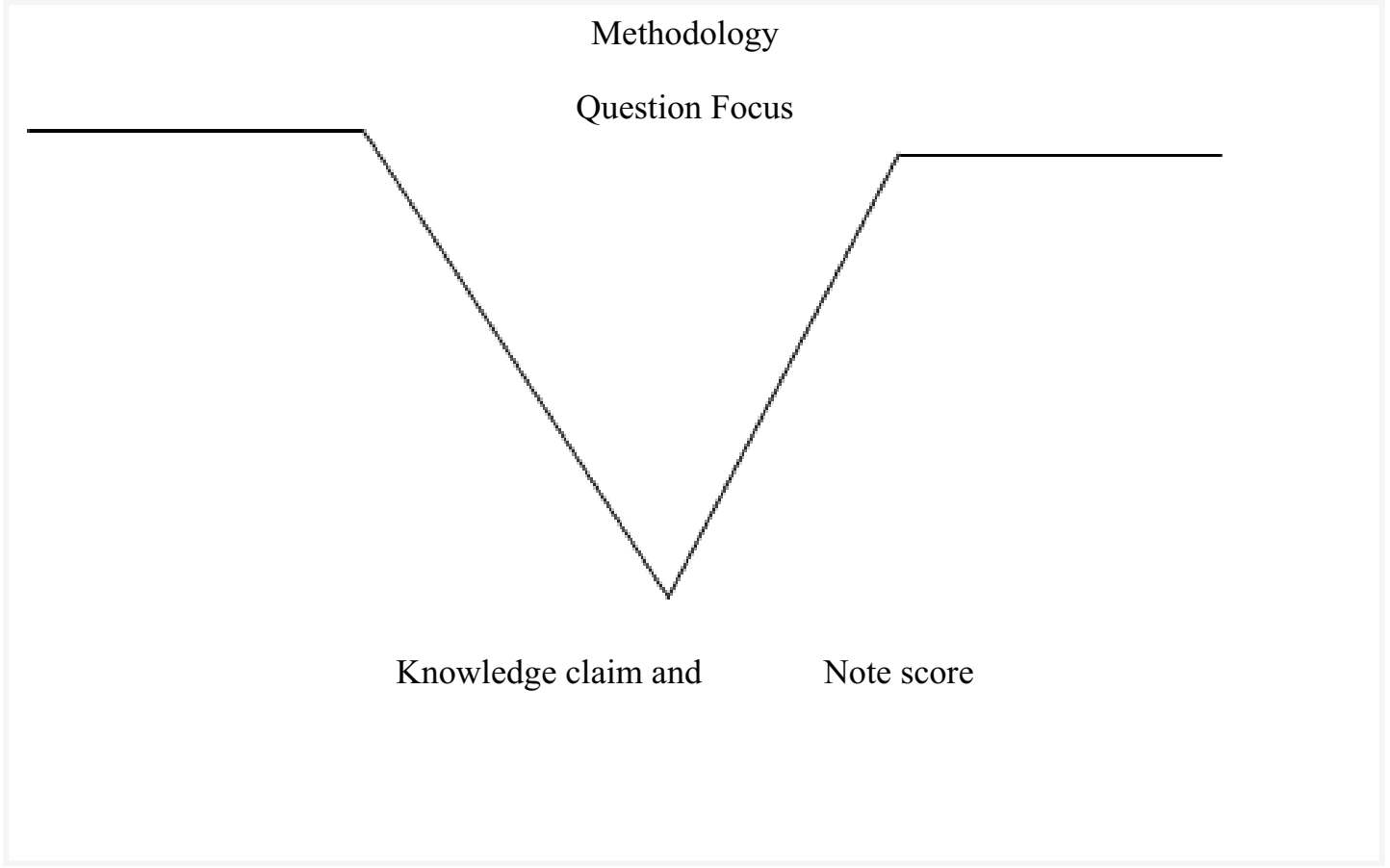

Figure 1: Vee map.

into a meaningful framework of ideas. A concept map can be used as an effort in more effective learning [10]. Furthermore, Sellman et al. [11] argue that a CM can serve as a tool for analyzing concepts in science. A CM is a method of concept mapping using a connector that indicates a link between two or more concepts. The link between two or more of these concepts can help students to write down ideas well.

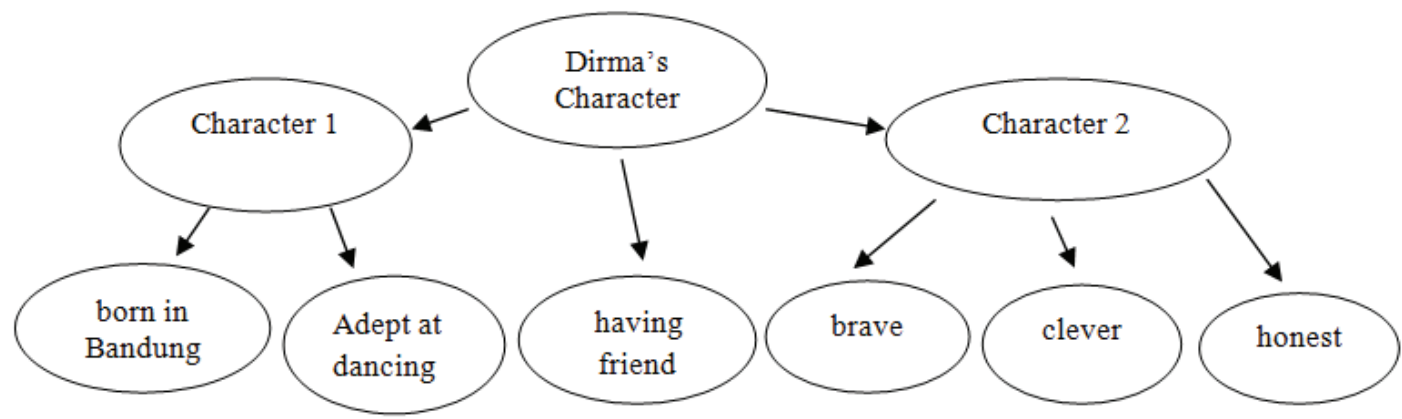

Figure 2: Concept map in the form of hierarchy.

Attitude is a form of evaluation or reaction of feeling that supports or does not support an object [12]. Attitude is a tendency to act positively toward a particular object, institution, concept, or person. In this study, students' attitudes are attitudes toward CIMM, VM, and CM applications. Those attitudes are divided into three subscales, namely the attitude of confidence, preferences, and academic efforts with the application of CIMM, VM, and CM in learning to write short stories. Confidence (C), 
preference $(P)$, and academic effort (AE) are measured by giving a questionnaire using a Likert scale.

\section{Methods}

This research uses an experimental method. The research population was all the students of XI grade SMA Negeri 13 Palembang. The sample of this research was XI grade MIA 2 with 38 students, XI grade MIA 3 with 32 students, and XI grade MIA 4 with 36 students. These three classes were assumed to have the same learning ability not the superior classes and were parallel classes and taught by the same teacher, for an equal number of hours, and with the same curriculum. This was to show that these three classes were representative.

The data collection technique used was a test. This was used to determine the students' ability to write short stories. The test was conducted before and after treatment [13]. Students were asked to write short stories in accordance with the learning techniques used in each class. The data for students' attitude was processed from the questionnaire given to the students. The questionnaire contained 45 questions consisting of 15 questions about beliefs, 15 questions about preference, and 15 questions about academic endeavors.

\section{Results}

\subsection{Students' ability in writing short story}

A homogeneity test was performed by using the gained data from the three groups, namely CIMM, VM, and CM. Table 1 shows that the data is not homogeneous. This is seen from the significance (sig. $0.03<0.05$ ). Therefore, data analysis was performed using Welch and Brown and Forsythe exams.

TABLE 1: Data homogeneity test.

\begin{tabular}{|l|c|c|c|}
\hline Levene Statistic & $\mathbf{d f 1}$ & $\mathbf{d f 2}$ & Sig. \\
\hline 5.991 & 2 & 103 & .003 \\
\hline
\end{tabular}

According to Table 2, the Welch and Brown-Forsythe tests show that there is a significant difference between the three groups of data. For further tests the KruskalWallis test was used. This was done to prove the significance of data more real. The Kruskal-Wallis test results can be seen in Table 3 below. 
TABLE 2: Test of significance of data with Welch and Brown-Forsythe tests.

\begin{tabular}{|l|c|c|c|c|}
\hline & Statistic & df1 & df2 & Sig \\
\hline Welch & 22.88 & 2 & 62.92 & .000 \\
\hline Brown-Forsythe & 25.08 & 2 & 80.75 & .000 \\
\hline
\end{tabular}

TABLE 3: Kruskal-Wallis nonparametric statistics.

\section{Null Hypothesis}

The gained distribution is the same for the group category

Test
Kruskal-Wallis

Sig.

.000

\section{Statement}

Reject Null

Hypothesis

The Kruskal-Wallis test results in Table 3 show that the data between the three groups show a significant difference of 0.000 at the 0.05 significance level. Thus, the null hypothesis that expresses the same gained distribution for all categories is rejected as seen in the statement column. The results of this analysis indicate that there is an ordered mean of the three groups of CIMM, VM, and CM.

TABLE 4: Average comparison of pre- and posttest.

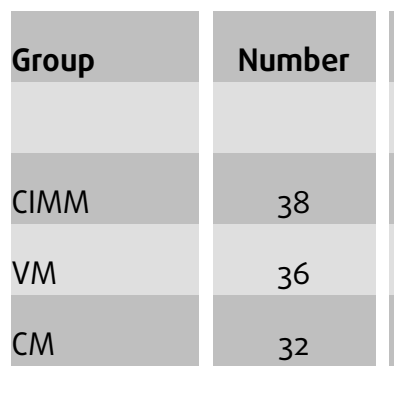

\begin{tabular}{|c|c|}
\hline \multicolumn{2}{|c|}{ Mean } \\
\hline Pre & Post \\
\hline 63.2 & 77.3 \\
\hline 64.3 & 72.8 \\
\hline 64.2 & 69.7 \\
\hline
\end{tabular}

Table 4 above shows that the average difference between the pre- and posttest for the CIMM collection compared with VM is 4.5 (77.3-72.8), the average difference group between VM and CM is 3.1 (72.8-69.7) while the average difference of group between CIMM and CM is 7.6 (77.3-69.7). A big difference is seen in the group taught with CIMM compared to the VM and CM techniques. This shows that there are different results of the learning outcomes of the three groups in writing short stories.

TABLE 5: Significance of differences test.

\begin{tabular}{l|c|c|c|c|c|c|}
\hline SoV & SS & Df & MS & F & P-value & F crit \\
\hline $\begin{array}{l}\text { Among } \\
\text { group }\end{array}$ & 1389.1 & 2 & 694.56 & 24.24 & $2.35996 \mathrm{E}-09$ & 3.084577 \\
\hline $\begin{array}{l}\text { In group } \\
\text { Total }\end{array}$ & $\mathbf{2 9 5 1 . 4}$ & 103 & 28.654 & & & \\
\hline
\end{tabular}


Table 5 shows that there are significant differences between the three sets (CIMM, $V M$, and $(M)$ due to the $p$-value of 0.00000000236 . This data indicates that there is a possibility that CIMM is different from VM, and CIMM is different from CM, but it is also possible that VM and CM are not necessarily different. Therefore, it is necessary to do a post hoc test using the Tamhane test.

TABLE 6: Tamhane statistics test.

\begin{tabular}{|c|c|c|c|c|}
\hline Test & (I) Group & (J) Group & Different Mean (I-J) & Sig. \\
\hline CIMM & VM & $5.62774^{*}$ & .001 \\
\hline Tamhane & & CM & $8.51316^{*}$ & .000 \\
\hline VM & CIMM & $-5.62774^{*}$ & .001 \\
\hline & CM & $2.88542^{*}$ & .017 \\
\hline & CIMM & $-8.51316^{*}$ & .000 \\
\hline & VM & $-2.88542^{\star}$ & .017 \\
\hline
\end{tabular}

Table 6 shows that there are significant differences between the three groups of data (pairwise). Comparison of the three groups namely CIMM, VM, and CM of each significance (sig < 0.05). Different mean of CIMM and VM is 5.62774 with a significance of.001, CIMM and CM is 8.51316 with a significance of 0.000. VM and CIMM show a mean difference of -5.62774 with a significance of.001. VM and CM show a mean difference of 2.88542 with a significance of.017. CM and CIMM show a different mean of -8.51316 with a significance of.ooo. CM and VM show a different mean of -2.88542 with a significance of.017.

Post hoc tests are conducted with Dunnett's T3 to ascertain which groups are different.

TABLE 7: Dunnett's T3 statistical test.

\begin{tabular}{|c|c|c|c|c|}
\hline Test & Group I & Group J & Different Mean (I-J) & Sig. \\
\hline & CIMM & VM & $5.62774^{\star}$ & .001 \\
\hline & & CM & $8.51316^{\star}$ & .000 \\
\hline Dunnett's T3 & VM & CIMM & $-5.62774^{\star}$ & .001 \\
\hline & & CM & $2.88542^{\star}$ & .017 \\
\hline & CM & CIMM & $-8.51316^{\star}$ & .000 \\
\hline & VM & $-2.88542^{*}$ & .017 \\
\hline
\end{tabular}

Table 7 shows that there are significant differences for the three data sets (pairwise). The CIMM versus the VM group has significant differences (sig $0.01<0.05$ ). Similarly, 
among groups of CIMMs compared to CM groups there is a very significant difference (sig. $0.000<005$ ). However, when comparing VM with $C M$, there is no significant difference (sig. $0.17>0.05$ ).

\subsection{Students' attitude}

The Mancova test was applied to determine the effect of independent variables (CIMM, VM, and $C M$ ) on the dependent variable (attitude of confidence subscale, preference, and academic effort) by using Pillai's Trace test, Wilks' Lambda, Hotelling's Trace, and Roy's Largest Root.

Table 8 shows that there are significant independent variables $(F=4.114$ with $p<$ 0.05), which is evident from the multivariate test decision with Pillai's Trace test (sig. 0.001), Wilks' Lambda (sig. 0.01), Hotelling's Trace and Roy's Largest Root (each sig. 0.000). This decision indicates that CIMM, VM, and CM are factors that influence the attitude subscales of confidence preference, and academic efforts.

Significantly, the effect of independent variables (CIMM, VM, and CM) on the dependent variable can be seen. The results show that the attitude subscale of confidence has $F(1.106)=121.008, p<0.05$, that of preference has $F(1.106)=4.881, p<0.05$ and that of academic efforts has $F(1.106)=8.118, p<0.05$.

The Squared $R$ value in Table 8 shows that the free variable contributes as much as a 0.726 or $72.6 \%$ change in the dependent variable subscale of confidence attitude. The attitude subscale of preference contributes a 0.996 or $99.6 \%$ change in the dependent variable of the attitude subscale of preference. The attitude subscale of academic efforts accounts for a 0.957 or $95.7 \%$ change in the dependent variable of the attitude subscale of academic efforts.

For the mean comparison of the dependent variable with the three groups the mean of each group was analyzed.

In Table 9 it is explained that the average attitudes subscale of post-academic efforts between the three groups is different. The mean of attitudes subscale of the postacademic effort of students taught by CIMM is greater than for those taught using the VM and $C M$ techniques.

The pretests of the CIMM, VM, and CM groups show no significant difference because only 0.01 or less than 1. Posttest results indicate that there is a difference in mean score test between the three groups. These results indicate that there are significant differences in the results of short story writing. The average results of the 
TABle 8: Mancova Test of Attitude Subscale of Confidence, Preference, and Academic Effort.

\begin{tabular}{|c|c|c|c|c|c|c|}
\hline \multirow[t]{2}{*}{ DV/ IDV } & Test & Score & $\mathbf{F}$ & $\begin{array}{c}\text { Hypothesis } \\
\text { df }\end{array}$ & Error df & Sig. \\
\hline & Pillai's Тrace & .222 & 4.114 & 6.000 & 198.000 & .001 \\
\hline \multirow[t]{3}{*}{ Groups } & Wilks' Lambda & .785 & $4.201^{b}$ & 6.000 & 196.000 & .001 \\
\hline & Hotelling's Trace & .265 & 4.286 & 6.000 & 194.000 & .000 \\
\hline & Roy's Largest Trace & .227 & $7.496^{c}$ & 3.000 & 99.000 & .000 \\
\hline \multirow[t]{5}{*}{ C-pre } & Pillai's Trace & .550 & $39.885^{b}$ & 3.000 & 98.000 & .000 \\
\hline & Wilks' Lambda & .450 & $39.885^{b}$ & 3.000 & 98.000 & .000 \\
\hline & Hotelling's Trace & 1.221 & $39.885^{b}$ & 3.000 & 98.000 & .000 \\
\hline & Roy's Largest Trace & 1.221 & $39.885^{b}$ & 3.000 & 98.000 & .000 \\
\hline & Pillai's Trace & .992 & $3815.060^{b}$ & 3.000 & 98.000 & .000 \\
\hline \multirow[t]{3}{*}{ P-pre } & Wilks' Lambda & .008 & $3815.060^{b}$ & 3.000 & 98.000 & .000 \\
\hline & Hotelling's Trace & 116.788 & $3815.060^{b}$ & 3.000 & 98.000 & .000 \\
\hline & Roy's Largest Trace & 116.788 & $3815.060^{b}$ & 3.000 & 98.000 & .000 \\
\hline \multirow[t]{4}{*}{ AE-pre } & Pillai's Trace & .898 & $286.281^{b}$ & 3.000 & 98.000 & .000 \\
\hline & Wilks' Lambda & .102 & $286.281^{b}$ & 3.000 & 98.000 & .000 \\
\hline & Hotelling's Trace & 8.764 & $286.281^{b}$ & 3.000 & 98.000 & .000 \\
\hline & Roy's Largest Trace & 8.764 & $286.281^{b}$ & 3.000 & 98.000 & .000 \\
\hline \multicolumn{7}{|c|}{ a. R Squared =.726 (Adjusted R Squared =.712) } \\
\hline \multicolumn{7}{|c|}{ b. R Squared =.996 (Adjusted R Squared =.996) } \\
\hline \multicolumn{7}{|c|}{ c. R Squared =.957 (Adjusted R Squared $=.955$ ) } \\
\hline \multicolumn{7}{|c|}{ d. Computed using alpha $=.05$} \\
\hline \multicolumn{7}{|c|}{ Explanation: } \\
\hline \multicolumn{7}{|c|}{ IDV = independent variable } \\
\hline \multicolumn{7}{|c|}{ DV = dependent variable } \\
\hline \multicolumn{7}{|c|}{ KY-pre $=$ attitude subscale of confidence pretest } \\
\hline KS-pre = & titude subscale of pre & ce prete & & & & \\
\hline
\end{tabular}

short story group taught by CIMM are higher than those taught using the VM and CM techniques.

Learning by using CIMM can improve the students' ability to write short stories at SMAN 13 Palembang due to the clear, directed, and creative learning steps. The results 
TABLE 9: Comparison of mean scores of groups.

\begin{tabular}{|c|c|c|c|c|}
\hline \multirow[t]{2}{*}{ DV } & Groups & Numbers & Mean & Standard error \\
\hline & CIMM & 38 & $58.539^{a}$ & .657 \\
\hline \multirow[t]{3}{*}{ C-post } & VM & 32 & $57.251^{a}$ & 699 \\
\hline & CM & 36 & $57.235^{a}$ & .659 \\
\hline & CIMM & 38 & $57.043^{a}$ & .091 \\
\hline \multirow[t]{3}{*}{ P-post } & VM & 32 & $57.122^{a}$ & .097 \\
\hline & CM & 36 & $56.735^{a}$ & .092 \\
\hline & CIMM & 38 & $57.181^{a}$ & .242 \\
\hline \multirow[t]{2}{*}{ AE-post } & VM & 32 & $56.504^{a}$ & .258 \\
\hline & CM & 36 & $55.778^{a}$ & .243 \\
\hline
\end{tabular}

of this study prove that CIMM can improve the students' ability to write short stories at SMAN 13 Palembang. The results of this study also support what is proposed by Buzan [6], Mahamod [7], Hernowo [5], Holiah and Indrawati [14], Ernalida and Ayob [15], and Hariri [16] that mind mapping can be used in learning to enhance students' creativity.

In addition, the application of CIMM may influence students' attitudes. This supports Ayob's research [17] on the university's preference attitude and confidence in the use of multimedia.

\section{Conclusion}

The results of the analysis indicate that there is a difference in the ability to write short stories between students taught by CIMM and those taught using VM and CM techniques. Thus, CIMM can be used in learning to write short stories by following the steps of learning systematically. Teachers are advised to use CIMM as an alternative in learning to write short stories in high school. This technique can be modified by the teacher according to the situation and conditions in the classroom or in each school.

\section{References}

[1] Susiawati S: Penerapan strategi peta konsep dalam keterampilan menulis cerita pendek siswa kelas XI SMA Negeri 1 Kota Batu Tahun Pelajaran 2013/2014 
[Implementation of concept map strategy in the skill of writing short story grade XI students SMA Negeri 1 Batu Town Lesson Year 2013/2014]. Journal NOSI. 2014; 2: $104-112$

[2] Ayob A, Idris MR, Shaari MR: Aspek kemahiran berbahasa [Aspects of language proficiency]. Tanjong Malim, Perak: Emiritus Publications; 2010.

[3] Nachiappan S: Gaya bahasa dan proses kognisi: kaedah pedagogi hermeneutik dan interpretasi [Language style and cognition process: hermeneutic pedagogy and interpretation]. Tanjong Malim, Perak: UPSI; 2014.

[4] Brandon L, Brandon K: Paragraphs and essays with integrited readings. Boston: Wadsworth; 2013.

[5] Hernowo: Quantum writing: cara cepat nan bermanfaat untuk merangsang munculnya potensi menulis [Quantum writing: a quick and useful way to stimulate the potential of writing]. Bandung: MLC; 2003.

[6] Buzan T: Panduan kemahiran belajar buzan. cara mudah mencapai kejayaan dalam pengajian anda, dengan teknik peta minda, bacaan laju dan penguasaan daya ingatan [Buzan learning proficiency guide. easy ways to achieve glory in your study, with map technique technique, rate reading and mastery of memory]. Kuala Lumpur: Utusan Publication \& Distributors Sdn Bhd; 2010.

[7] Mahamod Z: P\&P dalam pendidikan bahasa melayu [P\&P in malay language education]. Tanjung Malim: UPSI; 2014.

[8] Ayob A, Bakar A, Kasa Z, Yunus AS: Multimedia dalam Pengajaran Bahasa Melayu [Multimedia in Malay Language Teaching]. Selangor: Emeritus Publication; 2011.

[9] Sariyan A: Tertib mengarang: asas retorik untuk pelajar dan pendidik [Orderly compose: the rhetorical principle for students and educators]. Kuala Lumpur: Dewan Bahasa dan Pustaka; 2015.

[10] Osman K, Wahidin M, Mohd S. Concept mapping in chemistry lessons: tools for inculcating thinking skills in chemistry learning. J Baltic Sci Edu. 2013; 12: 666-681.

[11] Sellman D, Anne KL, Frans XB: Concept maps in the classroom: a new approach to reveal students' conceptual change. J Edu Res. 2015; 108: 250-257.

[12] Azwar S: Sikap manusia teori dan pengukurannya [Human attitude theory and its measurement]. Yogyakarta: Pustaka Pelajar; 2009.

[13] Creswell JW: Research design: qualitative and quantitative approach. California: Sage Publications Inc; 2012.

[14] Holiah P, Indrawati S: Kefektifan Model Pemetaan Pikiran dalam Pembelajaran Membaca Pemahaman Siswa Kelas X SMA Negeri 3 Palembang [The Effectiveness 
of Mind Mapping Model in Learning to Read Understanding of Students of Class X of SMA Negeri 3 Palembang]. Lingua: Jurnal Bahasa dan Sastra. 2008; 10: 40-46.

[15] Ernalida \& Ayob A: Pengaruh mind mapping terhadap kemampuan menulis cerpen siswa sma negeri 19 palembang [The influence of mind mapping to the ability of writing short stories students of state senior high school 19 palembang]. Logat: Jurnal Bahasa Indonesia dan Pembelajaran. 2015; 2: 25-30.

[16] Hariri M: The Attitude of EFL Learner Toward Using Mind Mapping Software on Their Reading Comprehension. Int J Lang Learn Appl Linguist World. 2013; 4: 334-341.

[17] Ayob A: Sikap kesukaan dan keyakinan belia universiti terhadap penggunaan multimedia [Attitude and beliefs of the universe against the use of multimedia]. Malays J Youth Stud. 2012; 7: 34-53. 